\title{
Maize Variety Screening against Maize Weevil Sitophilus zeamais under Storage in Chitwan Condition of Nepal
}

\author{
S. Sharma ${ }^{1, *}$, S. Tiwari ${ }^{2}$ \\ ${ }^{1}$ Nepal Agriculture Research Council, Nepal \\ ${ }^{2}$ Department of Entomology, Agriculture and Forestry University, Nepal
}

Copyright $\bigcirc 2016$ by authors, all rights reserved. Authors agree that this article remains permanently open access under the terms of the Creative Commons Attribution License 4.0 International License

\begin{abstract}
Eight different varieties like QPM, Rampur Composite, RML, Mankamana-4, Arun-2, Across, Deuti and Manakamana-3 were used for varietal screening against maize weevil damage. The research was done in free-choice and no-choice conditions. Deuti variety of maize was the most susceptible variety and grain damage was recorded up to $40 \%$ whereas in long term storage condition, Across $(44.81 \%)$ was the most suitable variety for weevils. The RML variety of maize was the least damaged variety and loss recorded about $18.12 \%$ in 60 days of observations. But while calculating the weight loss of the weevil, the loss $7.66 \%$ recorded in 60 days of observation in Across Variety, $6.26 \%$ in 40 days of observation in QPM and 5.06\% were recorded in Deuti, whereas the lowest percent weight loss was recorded in Manakamana-4 that was $1.80 \%$ and $1.00 \%$ in 40 days and 60 days respectively. Maximum number of F1 progenies were observed in across (74.00) and lowest were emerged in Rampur composite (32.33) and RML (32.67). The lowest germination loss was recorded in QPM $(8.00 \%)$, followed by Rampur Composite (10.00\%) and RML $(12.67 \%)$ respectively.
\end{abstract}

Keywords Maize Weevil, Sitophilus zeamais, Stored Grain, Varietal Screening

\section{Introduction}

Maize Weevil Sitophilus zeamais Mots, 1855 is one of the most serious, internal feeding pests of maize seed and grain. Dobie [5] reported that S. zeamais are found in all warm and tropical parts of the world. The maize weevil commonly attacks standing crops, in particular, maize before harvest, and is commonly associated with rice. The report [3] showed that it infests cereals, such as Wheat, oats, barley, sorghum, rye and Buckwheat.

Prakash et al. [11] reported that the male and female weevil is distinguished on the basis of length of snout. The male rostrum is smaller and bears pits on its anterior portion whereas it is larger with no pits in female. Similarly, Neupane [9] demonstrated that a single female may lay as many as 300-400 eggs, which hatch in 4-6 days. Generally it completes lifecycle in 35 to 43 days [10]. The actual quantitative loss from the $100 \%$ infested grains was estimated to be $10-20 \%$. Singh et al. [12] reported the loss ranged upto $11-23 \%$ due to insects' damage during storage. The susceptibility of the maize towards the weevil is assumed to be the starch content of the maize. The research of Golob [8] showed that dent maize tends to be more susceptible and flint maize resistant. Kernel size and husk cover also play a vital role in management of the maize weevil. The research [3] demonstrated that the degree of tightness and the extension of the husk cover both affect pre-harvest infestation by storage pests. Similarly, research [8] showed the local varieties of maize with good husk cover and grains are relatively resistant to insect attack but low yielding, synthetic varieties are low yielder but resistant to insect attack and composite varieties are intermediate. Nutrient constituents in different genotypes play a significant role in the feeding behavior of insects. The report of Entomology Division [6] reported that weevil multiplication depends on many factors such as temperature, moisture content of grains, hardness and softness of grain endosperm and quality of the grain. Thus, report [8] showed the number of eggs laid and their potential to develop into adults and time to complete its development period may differ on type of wheat genotypes. Campbel [2] reported that females accepted large sized kernels more quickly than small kernels and this contributed to increased oviposition in large kernel. In those research areas including whole hilly areas of Nepal, farmers were commonly have been using and based on the farmers experiences improved and hybrid varieties are more vulnerable for weevil damage in comparison to the local varieties. But such kind of varietal preferences studies have not studied yet. Realizing the fact, the study was conducted to find out more resistant varieties of weevil in Chitwan condition of Nepal.

\section{Materials and Methods}

\section{Seed selection}

Different common and popular varieties like QPM, 
Rampur Composite, RML, Mankamana-4, Arun-2, Across, Deuti and Manakamana-3 were collected. The seed collected from different sources was cleaned and dried in the sun. The moisture level was maintained from $12-13 \%$. The moisture level of the seed was measured by Willy Dividable moisture meter.

\section{Mass production of weevils}

Live insect specimens of $S$. zeamais were collected from insect infested stores. QPM maize variety was used for insect rearing in a large cloth bag. Maintenance and mass rearing of insect was performed at room temperature in Rampur IAAS. These reared insects were utilized for testing with different collected varieties of maize and for the host preference study.

\section{Varietal screening in free choice and no-choice conditions}

Eight different varieties were tested in no-choice and free choice condition which was replicated thrice. The weevil's effect on the variety was tested in two different conditions. One was free choice condition, where insects were allowed to move freely in different varieties. Fifty grams of each of the eight varieties were set in each petriplate in free choice condition, which was confined in large circular bucket in circular manner. The large bucket from outside was covered by barber net to prevent from the escaping of weevils. Similarly, fifty grams of seeds was taken in a plastic jar of half $\mathrm{kg}$ capacity. To facilitate proper aeration and ventilation, the mouth of the jar was covered with the help of barber net.

\section{Release of weevils in free and no-choice condition}

Fourty pairs of newly emerged adult of $S$. zeamais were released in the center of the chamber for oviposition in free choice condition. The whole set of experiment were covered by specially designed mosquito nets to prevent from escaping of weevils. Adult weevils were removed after seven days of weevil release. The experiment was laid out in Complete Randomized Design (CRD) which was replicated thrice. Where as in no-choice condition, five pairs of male and female of newly emerged weevil were released in each container obtained from laboratory culture. The several research $[1,7]$ showed that the male and female maize weevil

The released weevils were removed after seven days from the container. And necessary data were observed and recorded after ten days of experiment set up and subsequent data (number and weight of grain damage) were recorded at 10-day intervals. For F1 progeny population, collection of data started after twenty five days of the weevil removal and observation for the progeny was continued daily at the same time for 20 days. The following parameters were observed during data recording.

- Germination\% before experimental setup and at the end of the experiment.

- Number of damaged / undamaged grains

- Weight of damaged / undamaged grains

- Moisture $\%$ of grains

- No. of F1 progeny

- Room temperature and R. H.

In this experiment mean comparison of these characters was calculated by using Least Significant Difference (LSD) method. The study was concluded on the basis of its results, i.e., significant or not significant at $5 \%$ and $1 \%$ probability level.

\section{Result and Discussion}

\section{Free choice test}

The grain damage percent was significantly different $(\mathrm{P}<0.05)$ among the tested varieties during 20,40 and 60 days after observations in free-choice condition (Table 1). In 20 days after treatment maximum percent loss was recorded in Deuti (2.38\%) and Manakamana-3 (1.91\%) varieties whereas lowest percent loss was recorded in Rampur Composite $(0.24 \%)$ and RML $(0.42 \%)$. Similarly, maximum percent loss in 40 days of observation was recorded in Deuti (24.33\%) followed by Across (23.44\%), QPM (16.67\%), Manakamana-4 (16.43\%), Arun-2 (15.89\%), Manakamana-3 (15.47\%), Rampur composite (14.56\%) and lowest percent loss in RML (11.87\%), respectively. However, in 60 days of observation, the grain damage percent was recorded highest in Across (44.81\%), followed by Dueti (39.15\%) and least loss were recorded in RML (18.12\%) and Rampur composite $(28.15 \%)$, respectively.

Table 1. Varietal preferences of Maize weevil, S. zeamais under free-choice condition at Rampur, Chitwan, Nepal, 2013

\begin{tabular}{cccc}
\hline \multirow{2}{*}{ Maize variety } & \multicolumn{2}{c}{ Percent Grain Damage (No. basis) at indicated days after treatment } \\
\cline { 2 - 4 } & 20 & 40 & 60 \\
\hline QPM & $0.99^{\mathrm{ab}} \pm 0.34$ & $16.67^{\mathrm{abc}} \pm 3.31$ & $29.17^{\mathrm{abc}} \pm 0.60$ \\
Rampur Composite & $0.24^{\mathrm{b}} \pm 0.43$ & $14.56^{\mathrm{bc}} \pm 1.13$ & $28.15^{\mathrm{bc}} \pm 2.22$ \\
RML & $0.42^{\mathrm{b}} \pm 0.36$ & $11.87^{\mathrm{c}} \pm 1.65$ & $18.12^{\mathrm{c}} \pm 3.80$ \\
Mankamana-4 & $1.42^{\mathrm{ab}} \pm 0.72$ & $16.43^{\mathrm{abc}} \pm 1.43$ & $33.09^{\mathrm{abc}} \pm 5.99$ \\
Arun-2 & $0.97^{\mathrm{ab}} \pm 0.33$ & $15.89^{\mathrm{abc}} \pm 1.21$ & $32.56^{\mathrm{abc}} \pm 4.19$ \\
Across & $0.48^{\mathrm{b}} \pm 0.48$ & $23.44^{\mathrm{ab}} \pm 6.90$ & $44.81^{\mathrm{a}} \pm 12.42$ \\
Deuti & $2.38^{\mathrm{a}} \pm 2.10$ & $24.33^{\mathrm{a}} \pm 4.58$ & $39.15^{\mathrm{ab}} \pm 7.95$ \\
Manakamana-3 & $1.91^{\mathrm{ab}} \pm 0.83$ & $15.47^{\mathrm{abc}} \pm 2.51$ & $34.28^{\mathrm{abc}} \pm 4.46$ \\
P Value & $<0.05$ & $<0.01$ & $<0.01$ \\
CV \% & 18.97 & 19.71 & 19.22 \\
LSD Value & 1.545 & 8.14 & 14.86 \\
Sem \pm & 0.52 & 1.97 & 3.60 \\
\hline
\end{tabular}

$\mathrm{CV}$ : coefficient variation; LSD: least significance difference; * means followed by the same letters in a column are not significantly different by DMRT at $\leq 0.05$ level, value after \pm is the standard error of mean. 
The weight loss percent among varieties were highly significant $(\mathrm{P}<0.01)$ in 20 days, 40 days and 60 days of observations (Table 2). The highest percent weight loss was recorded in Deuti $(3.60 \pm 0.20)$ followed by QPM (3.33 \pm $0.31)$, across $(2.93 \pm 1.10)$ respectively. The two varieties QPM and Deuti were not statistically different in percent weight loss. Similarly in 20 days of observation, the two varieties Manakamana-4 and Arun-2 were not statistically different and more or similar with the other varieties (Table 2). In 40 days of observation, the varieties Rampur Composite, RML, Manakamana-4 and Arun-2 were statistically at par but QPM, Across, and Deuti were statistically similar. (Table 2). In 60 Days of observation, QPM was statistically similar with Across and difference with other varieties.

\section{F1 Progeny of weevil in different varieties}

The number of progeny emergence in different days ( 40 and 60 days) of observations were statistically different $(\mathrm{P}<0.05)$. In 20 days of observation, the progeny emergence were similar. Highest number of progenies emerged in

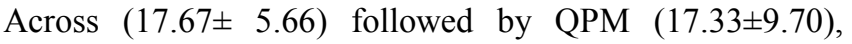

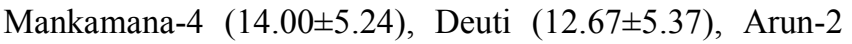
$(11.66 \pm 0.58)$ and lowest number of weevil emerged in Rampur composite (10.00土1.73), Manakamana-3 (10.67 $\pm 1.53)$ and RML (11.33 \pm 5.86$)$, respectively (Table 3$)$. In 40 days of treatment set up, progeny emergence within the treatments were statistically different. Across and RML were statistically different. Maximum number of weevils were observed in Across (38.33 \pm 4.51$)$ and lowest number of progenies were observed in RML $(16.00 \pm 6.08)$. Whereas in 60 days of observation, the number of progeny emergence in Across was statically different with RML and Rampur composite. About same numbers of progenies were observed in Manakamana-4 (52.67 \pm 39.46$)$, QPM $(50.00 \pm 14.80)$, Arun-2(49.33 \pm 13.05$)$ and Deuti $(45.67 \pm 8.02)$ maize varieties. Similarly, Rampur composite (32.33 \pm 7.37$)$, RML $(32.33 \pm 7.37)$ and Manakamana-3 (39.33 \pm 16.01$)$ were similar in terms of progeny emergence (Table 3 ).

Table 2. Varietal preferences of Maize weevil, S. zeamais under free-choice condition at Rampur Chitwan, Nepal, 2013

\begin{tabular}{|c|c|c|c|}
\hline \multirow{2}{*}{ Maize variety } & \multicolumn{3}{|c|}{ Percent Grain Damage (Wt. basis) at indicated days after treatment } \\
\hline & 20 & 40 & 60 \\
\hline QPM & $3.33^{\mathrm{a}} \pm 0.31$ & $5.73^{\mathrm{a}} \pm 0.95$ & $7.66^{\mathrm{a}} \pm 0.42$ \\
\hline Rampur Composite & $0.80^{\mathrm{c}} \pm 0.40$ & $1.93^{\mathrm{c}} \pm 0.23$ & $4.53^{\mathrm{c}} \pm 1.10$ \\
\hline RML & $1.26^{\mathrm{bc}} \pm 1.50$ & $2.26^{\mathrm{c}} \pm 0.64$ & $3.80^{\mathrm{c}} \pm 0.80$ \\
\hline Mankamana-4 & $1.73^{\mathrm{abc}} \pm 0.31$ & $1.80^{\mathrm{c}} \pm 0.20$ & $1.00^{\mathrm{d}} \pm 1.00$ \\
\hline Arun-2 & $1.86^{\mathrm{abc}} \pm 0.23$ & $1.80^{\mathrm{c}} \pm 0.35$ & $1.26^{\mathrm{d}} \pm 0.76$ \\
\hline Across & $2.93^{\mathrm{ab}} \pm 1.10$ & $6.26^{\mathrm{a}} \pm 2.00$ & $7.33^{\mathrm{ab}} \pm 0.61$ \\
\hline Deuti & $3.60^{\mathrm{a}} \pm 0.20$ & $5.06^{\mathrm{ab}} \pm 0.12$ & $4.53^{\mathrm{c}} \pm 1.40$ \\
\hline Manakamana-3 & $1.73^{\mathrm{abc}} \pm 0.64$ & $3.33^{\mathrm{bc}} \pm 1.29$ & $5.13^{\mathrm{bc}} \pm 1.10$ \\
\hline P Value & $<0.01$ & $<0.01$ & $<0.01$ \\
\hline $\mathrm{CV} \%$ & 34.05 & 26.91 & 21.46 \\
\hline LSD Value & 1.752 & 2.262 & 2.25 \\
\hline $\mathrm{SEM} \pm$ & 0.42 & 0.55 & 0.55 \\
\hline
\end{tabular}

CV: coefficient variation; LSD: least significance difference; * means followed by the same letters in a column are not significantly different by DMRT at $\leq 0.05$ level, value after \pm is the standard error of mean.

Table 3. Maize weevil populations in different varieties of maize under free- choice condition at Rampur Chitwan, Nepal, 2013

\begin{tabular}{cccc}
\hline \multirow{2}{*}{ Maize variety } & \multicolumn{3}{c}{ Weevil Population (No.) at indicated days after treatment } \\
\cline { 2 - 4 } & 20 & 40 & 60 \\
\hline QPM & $17.33 \mathrm{a} \pm 9.70$ & $34.00 \mathrm{ab} \pm 19.05$ & $50.00 \mathrm{ab} \pm 14.80$ \\
Rampur Composite & $10.00 \mathrm{a} \pm 1.73$ & $20.00 \mathrm{ab} \pm 5.20$ & $32.33 \mathrm{~b} \pm 7.37$ \\
RML & $11.33 \mathrm{a} \pm 5.86$ & $16.00 \mathrm{~b} \pm 6.08$ & $32.67 \mathrm{~b} \pm 7.09$ \\
Mankamana-4 & $14.00 \mathrm{a} \pm 5.24$ & $30.00 \mathrm{ab} \pm 13.08$ & $52.67 \mathrm{ab} \pm 39.46$ \\
Arun-2 & $11.66 \mathrm{a} \pm 0.58$ & $25.67 \mathrm{ab} \pm 7.64$ & $49.33 \mathrm{ab} \pm 13.05$ \\
Across & $17.67 \mathrm{a} \pm 5.66$ & $38.33 \mathrm{a} \pm 4.51$ & $74.00 \mathrm{a} \pm 12.17$ \\
Deuti & $12.67 \mathrm{a} \pm 5.37$ & $35.33 \mathrm{ab} \pm 9.07$ & $45.67 \mathrm{ab} \pm 8.02$ \\
Manakamana-3 & $10.67 \mathrm{a} \pm 1.53$ & $21.67 \mathrm{ab} \pm 8.08$ & $39.33 \mathrm{~b} \pm 16.01$ \\
P Value & $>0.05$ & $<0.05$ & $<0.05$ \\
CV \% & 25.95 & 36.75 & 37.76 \\
LSD Value & 11.27 & 17.57 & 30.72 \\
Sem \pm & 3.76 & 5.86 & 10.25 \\
\hline
\end{tabular}

CV: coefficient variation; LSD: least significance difference; * means followed by the same letters in a column are not significantly different by DMRT at $\leq 0.05$ level, value after \pm is the standard error of mean. 


\section{No-choice condition}

\section{Grain damage percentage}

The grain damage percent in 20 days and 60 days of observations were highly significant $(\mathrm{P}<0.01)$ whereas in 40 days of treatment set up, the grain damage percent were significant $(\mathrm{P}<0.05)$. In 20 days, Deuti, Manakamana-3, Across, Manakamana-4 and QPM were statistically similar and more susceptible variety to weevil. Rampur composite $(0.49 \pm 0.43)$ and $\mathrm{RML}(0.21 \pm 0.36)$ varieties were least susceptible varieties of maize in terms of percent damage which were not statistically different with Manakamana-4, Arun-2 and Across. In 40 days, Deuti variety was statistically similar with other five different other varieties of maize and was the most susceptible variety with highest loss (14.55 \pm 3.01$)$ loss (Table 4) which are statistically similar with other five varieties but different with Rampur composite and RML. Whereas in 60 days of observation, Deuti was statistically different from Rampur composite, QPM and RML but similar with rest of other varieties. In other side, Arun-2 (18.79 \pm 4.21$)$, Rampur composite
(12.59 \pm 3.40$),$ RML (12.71 \pm 4.07$)$ and QPM (12.26 \pm 1.03$)$ were statistically similar and least damaged varieties among other varieties (Table 4).

In weight basis, the weight loss percent among the maize varieties were non-significant $(\mathrm{P}>0.05)$, and recorded statistically similar in 40 days and 60 days of observations though observed statistically different among the varieties after 20 days of treatment set up. In 20 days, maximum percent loss $(3.00 \pm 0.72)$ was recorded in Across variety which was statistically superior among the other treated

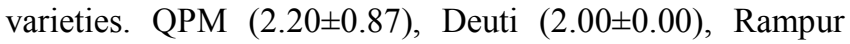
composite (1.66 \pm 0.58$)$, RML (1.60 \pm 0.20$)$, Manakamana-3 $(1.20 \pm 1.11)$ and Arun-2 $(1.13 \pm 1.03)$ respectively medium susceptible varieties and were statistically similar to each other. (Table 5). Similarly, in 40 days, all tested varieties were statistically similar $(\mathrm{P}>0.05)$ and maximum damage percent was recorded in QPM $(4.00 \pm 1.39)$ and lowest in RML (1.73 \pm 0.42$)$ maize variety. On the other hand, in 60 days, varieties were not statistically different and maximum susceptible variety was Across $(5.33 \pm 0.12)$ and least weight loss recorded in Manakamana-4 (2.73 \pm 3.04$)$ (Table 5).

Table 4. Varietal preferences of Maize weevil, S. zeamais under no-choice condition at Rampur Chitwan, Nepal, 2013

\begin{tabular}{|c|c|c|c|}
\hline \multirow{2}{*}{ Maize variety } & \multicolumn{3}{|c|}{ Percent Grain Damage (No. basis) at indicated days after treatment } \\
\hline & 20 & 40 & 60 \\
\hline QPM & $2.18^{\mathrm{ab}} \pm 0.69$ & $12.10^{\mathrm{ab}} \pm 0.69$ & $17.26^{\mathrm{b}} \pm 1.03$ \\
\hline Rampur Composite & $0.49^{\mathrm{c}} \pm 0.43$ & $5.92^{\mathrm{b}} \pm 1.29$ & $12.59^{\mathrm{b}} \pm 3.40$ \\
\hline RML & $0.21^{\mathrm{c}} \pm 0.36$ & $5.62^{\mathrm{b}} \pm 2.73$ & $12.71^{\mathrm{b}} \pm 4.07$ \\
\hline Mankamana-4 & $1.43^{\mathrm{abc}} \pm 0.00$ & $10.71^{\mathrm{ab}} \pm 4.34$ & $21.43^{\mathrm{ab}} \pm 8.66$ \\
\hline Arun-2 & $0.96^{\mathrm{bc}} \pm 0.67$ & $7.94^{\mathrm{ab}} \pm 2.42$ & $18.79^{\mathrm{b}} \pm 4.21$ \\
\hline Across & $1.28^{\mathrm{abc}} \pm 0.28$ & $12.44^{\mathrm{ab}} \pm 2.53$ & $24.08^{\mathrm{ab}} \pm 3.11$ \\
\hline Deuti & $2.11^{\mathrm{ab}} \pm 0.91$ & $14.55^{\mathrm{a}} \pm 3.01$ & $31.74^{\mathrm{a}} \pm 1.59$ \\
\hline Manakamana-3 & $2.61^{\mathrm{a}} \pm 0.83$ & $10.00^{\mathrm{ab}} \pm 3.98$ & $23.81^{\mathrm{ab}} \pm 3.94$ \\
\hline P Value & $<0.01$ & $<0.05$ & $<0.01$ \\
\hline $\mathrm{CV} \%$ & 42.08 & 28.87 & 10.31 \\
\hline LSD Value & 1.41 & 6.82 & 21.29 \\
\hline $\operatorname{Sem} \pm$ & 0.34 & 1.65 & 2.50 \\
\hline
\end{tabular}

$\mathrm{CV}$ : coefficient variation; LSD: least significance difference; * means followed by the same letters in a column are not significantly different by DMRT at $\leq 0.05$ level, value after \pm is the standard error of mean.

Table 5. Varietal preferences of Maize weevil, S. zeamais under no- choice condition at Rampur, Chitwan, Nepal, 2013

\begin{tabular}{cccc}
\hline \multirow{2}{*}{ Maize variety } & \multicolumn{2}{c}{ Percent Grain Damage (Wt. basis) at indicated days after treatment } \\
\cline { 2 - 4 } & 20 & 40 & 60 \\
\hline QPM & $2.20^{\mathrm{ab}} \pm 0.87$ & $4.00^{\mathrm{a}} \pm 1.39$ & $4.86^{\mathrm{a}} \pm 1.21$ \\
Rampur Composite & $1.66^{\mathrm{ab}} \pm 0.58$ & $2.46^{\mathrm{a}} \pm 0.64$ & $3.40^{\mathrm{a}} \pm 0.53$ \\
RML & $1.60^{\mathrm{ab}} \pm 0.20$ & $1.73^{\mathrm{a}} \pm 0.42$ & $3.40^{\mathrm{a}} \pm 0.40$ \\
Mankamana-4 & $0.73^{\mathrm{b}} \pm 1.10$ & $3.13^{\mathrm{a}} \pm 2.50$ & $2.73^{\mathrm{a}} \pm 3.04$ \\
Arun-2 & $1.13^{\mathrm{ab}} \pm 1.03$ & $2.13^{\mathrm{a}} \pm 0.81$ & $3.00^{\mathrm{a}} \pm 1.73$ \\
Across & $3.00^{\mathrm{a}} \pm 0.72$ & $3.60^{\mathrm{a}} \pm 0.35$ & $5.33^{\mathrm{a}} \pm 0.12$ \\
Deuti & $2.00^{\mathrm{ab}} \pm 0.00$ & $3.86^{\mathrm{a}} \pm 0.23$ & $3.00^{\mathrm{a}} \pm 1.00$ \\
Manakamana-3 & $1.20^{\mathrm{ab}} \pm 1.11$ & $2.26^{\mathrm{a}} \pm 1.70$ & $3.66^{\mathrm{a}} \pm 0.76$ \\
\hline P Value & $>0.05$ & $>0.05$ & $>0.05$ \\
CV \% & 47.48 & 43.07 & 38.11 \\
LSD Value & 1.91 & 2.97 & 3.34 \\
Sem \pm & 0.46 & 0.72 & 0.81 \\
\hline
\end{tabular}

CV: coefficient variation; LSD: least significance difference; * means followed by the same letters in a column are not significantly different by DMRT at $\leq 0.05$ level, value after \pm is the standard error of mean. 


\section{F1 Progeny emergence in both condition}

The data analysis regarding total number of progenies emergences from different tested varieties under free-choice and no-choice condition showed that varieties were significant non-difference under free-choice condition and significantly different under no-choice condition. Under free-choice condition, all tested varieties were similar in terms of progeny emergence $(\mathrm{P}>0.05)$. However, maximum number of progenies were emerged from Across (74 \pm 12.17$)$ followed by Manakamana-4 (52.66 \pm 39.46$)$, QPM $(50.00 \pm 14.80), \quad$ Deuti $\quad(39.33 \pm 14.05), \quad$ Manakamana-3 $(39.33 \pm 16.01)$, respectively. The lowest number of progenies emerged from two varieties Rampur composite $(32.33 \pm 7.37)$ and RML (32.66 \pm 7.09$)$. Hence, it is predicted that Rampur composite and RML maize varieties suffered low damage due to weevil. Similarly, in no-choice condition, the progeny numbers were significantly different to each other $(\mathrm{P}<0.01)$. Maximum number of progeny $(43.67 \pm 2.08)$ was recorded in Across maize variety which was statistically different with Rampur composite, QPM, RML, Manakamana-4 and Manakamana-4 (Table 6)

\section{Germination loss in both conditions}

The germination losses were statistically different each other. However, maximum germination loss difference was recorded in Across (18.67 \pm 3.21 ), which was statistically superior over other maize varieties and highly susceptible maize varieties by weevil. The lowest percent germination loss was recorded in QPM (8.00 \pm 2.00$)$ followed by Rampur

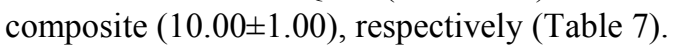

Table 6. Total numbers of F1 Progeny emergences of Maize weevil, S. zeamais in free-choice and no-choice condition at Rampur, Chitwan, Nepal, 2013

\begin{tabular}{|c|c|c|}
\hline \multirow{2}{*}{ Maize variety } & \multicolumn{2}{|c|}{ Number of F1 Progeny } \\
\hline & Free-choice condition & No-choice condition \\
\hline QPM & $50.00^{\mathrm{a}} \pm 14.80$ & $21.00^{\mathrm{bc}} \pm 3.61$ \\
\hline Rampur Composite & $32.33^{\mathrm{a}} \pm 7.37$ & $10.67^{\mathrm{c}} \pm 2.08$ \\
\hline RML & $32.66^{\mathrm{a}} \pm 7.09$ & $16.33^{\mathrm{bc}} \pm 5.86$ \\
\hline Mankamana-4 & $52.66^{\mathrm{a}} \pm 39.46$ & $21.00^{\mathrm{bc}} \pm 11.36$ \\
\hline Arun-2 & $49.33^{\mathrm{a}} \pm 13.05$ & $23.00^{\mathrm{abc}} \pm 19.08$ \\
\hline Across & $74.00^{\mathrm{a}} \pm 12.17$ & $43.67^{\mathrm{a}} \pm 2.08$ \\
\hline Deuti & $39.33^{\mathrm{a}} \pm 14.05$ & $36.00^{\mathrm{ab}} \pm 5.29$ \\
\hline Manakamana-3 & $39.33^{\mathrm{a}} \pm 16.01$ & $20.00^{\mathrm{bc}} \pm 6.00$ \\
\hline P Value & $>0.05$ & $<0.01$ \\
\hline LSD Value & 43.43 & 20.88 \\
\hline $\operatorname{Sem} \pm$ & 10.51 & 5.05 \\
\hline
\end{tabular}

CV: coefficient variation; LSD: least significance difference; * means followed by the same letters in a column are not significantly different by DMRT at $\leq 0.05$ level, value after \pm is the standard error of mean.

Table 7. Germination \% losses of different varieties by Maize weevil, S. zeamais Motsch at, Rampur Chitwan, Nepal, 2013

\begin{tabular}{|c|c|c|c|}
\hline \multirow{2}{*}{ Maize variety } & \multicolumn{3}{|c|}{ Germination \% } \\
\hline & Before treatment & After treatment & Actual germination loss \\
\hline QPM & $84.00^{\mathrm{abc}} \pm 3.61$ & $76.00^{\mathrm{a}} \pm 2.65$ & $8.00^{b} \pm 2.00$ \\
\hline Rampur Composite & $87.33^{\mathrm{ab}} \pm 2.52$ & $77.33^{\mathrm{a}} \pm 2.31$ & $10.00^{\mathrm{b}} \pm 1.00$ \\
\hline RML & $72.67^{\mathrm{d}} \pm 2.52$ & $60.00^{\mathrm{b}} \pm 0.00$ & $12.67^{\mathrm{ab}} \pm 2.52$ \\
\hline Mankamana-4 & $87.00^{\mathrm{ab}} \pm 2.00$ & $73.67^{\mathrm{a}} \pm 7.77$ & $13.33^{\mathrm{ab}} \pm 8.50$ \\
\hline Arun-2 & $83.67^{\mathrm{abc}} \pm 3.21$ & $72.67^{\mathrm{a}} \pm 6.81$ & $11.00^{\mathrm{b}} \pm 3.61$ \\
\hline Across & $92.00^{\mathrm{a}} \pm 3.46$ & $73.33^{\mathrm{a}} \pm 2.89$ & $18.67^{\mathrm{a}} \pm 3.21$ \\
\hline Deuti & $78.33^{\text {cd }} \pm 2.52$ & $65.00^{\mathrm{ab}} \pm 5.00$ & $13.33^{\mathrm{ab}} \pm 2.52$ \\
\hline Manakamana-3 & $83.00^{\mathrm{bc}} \pm 5.20$ & $70.33^{\mathrm{ab}} \pm 5.51$ & $12.67^{\mathrm{ab}} \pm 2.52$ \\
\hline P Value & $<0.01$ & $<0.01$ & $<0.05$ \\
\hline LSD Value & 20.50 & 12.50 & 6.69 \\
\hline Sem \pm & 1.89 & 2.76 & 2.23 \\
\hline
\end{tabular}

$\mathrm{CV}$ : coefficient variation; LSD: least significance difference; * means followed by the same letters in a column are not significantly different by DMRT at $\leq 0.05$ level, value after \pm is the standard error of mean. 


\section{Summary and Conclusions}

Under no-choice condition, the highest weevil population build up was observed in Across (43.67) and Deuti (36.00) and least in Rampur composite (10.67) and RML (16.33). Similarly, in free choice condition, highest weevil population were counted in Across (74.00) and Manakamana-4 (52.66) and least were counted in Rampur composite (32.33) and RML (32.66).

The maximum germination loss was recorded in Across $(18.67 \%)$ followed by Deuti (13.33\%), Manakamana-4 $(13.33 \%)$ and Manakamana-3 (12.6\%) respectively. Similarly, the lowest loss was recorded as in QPM $(8.00 \%)$, Rampur Composite (10.00\%) and Arun-2 (11.00\%), respectively. Hence, we can conclude that Rampur composite, RML and Manakamana were the most resistant varietyies against weevil and other varieties such as Across, Deuti and QPM were the most susceptible.

\section{Acknowledgements}

Tribhubhan University, IAAS, Rampur Campus, Entomology Laboratory and University Grant Commission are acknowledged for providing the research space and financial support respectively.

\section{REFERENCES}

[1] Boudreaux HB. The identify of Sitophilus orizae. Annals of the Entomological society of America.1969; 62: 169-170.

[2] Campbell JF. (2002). Influence of Seed Size on Exploitation by the Rice Weevil, Sitophilus oryzae. Journal of Insect
Behavior. 2002: 15(3): 429-445. Available from doi:10.1023/A:1016225427886

[3] Champ BR, Dyte, CE. FAO global survey of pesticide susceptibility of stored grain pests. FAO PL. Prot. Bull. 1977; 25(2): 49-67.

[4] Dobie P. The contribution of the tropical stored products center to the study of the insect resistance in stored maize. Tropical Stored Products Information. 1977: 34:7-22.

[5] Dobie P. 1974. The laboratory assessment of the inherent susceptibility of maize varieties to post harvest infestations by Sitophilus zeamais Mots. Journal of Stored Product Research. 1974; 10: 183-197.

[6] Entomology Division. Annual Technical Report of 1999/2000. Entomology Division Khumaltar: Agricultural Research Council Nepal; 2001. 20-24

[7] Floyd EH, Newson LD. Biological study of the rice weevil complex. Annals of the Entomological society of America. $1959 ; 62: 169-170$

[8] Golob P. Improvements in maize storage for the small holder farmer. Tropical Stored Products Information; 1984; 50: 14-19

[9] Neupane FP. Balibiruwa ka satru ra tinka roktham (crop pests and their control). Sajha Prakashan, Pulchowk, Nepal. 2002. $582 \mathrm{p}$.

[10] PHLRD. Post-harvest loss reduction. Progress report 2002/2003, directorate, Shreee Mahal, Pulchowk, Lalitpur, Nepal; 2002: 54p.

[11] Prakash A, Rao J, Pasalu IC, Mathur, KC. Rice storage and insect pest management. B. R. Publishing Corporation, Delhi. 1987: 321p.

[12] Singh, LK, Thapa RB, Pandey RS. Rat and insect problems in grain storage and their control strategies used by farmers of chitwan: IAAS Research Report, Chitwan, Nepal. 1992: 248-255. 